\title{
ROLL OVER TEST SEBAGAI PREDIKSI PRE EKLAMSI PADA IBU HAMIL
}

\author{
Awatiful Azza \\ Fakultas Ilmu KesehatanUniversitas Muhammadiyah Jember \\ E-mail : awatiful.azza@unmuhjember.ac.id
}

\begin{abstract}
Pre-eclampsia is a major cause of maternal death and it's one of the complications of pregnancy which has been increasing recently. The high morbidity of the preeclampsia incidence on pregnant women, it does not rule out the possibility of increasing the mortality of pregnant and childbirth due to preeclampsia, if early detection of risk factors and the initial treatment of pre-eclampsia is not done quickly and precisely.

Roll Over Test (ROT) is one physical examination of pregnant women, especially by using blood pressure measurements in two different positions, namely in the position of sleeping on the left side and supine sleeping position. Early detection is able to predict preeclampsia at maternal gestational age above 24 weeks. The rollover test is based on the observation that significant supine hypertension is present for a period of 8 to 10 weeks before the onset of preeclampsia. This certainly can help mothers prevent preeclampsia and can reduce maternal mortality due to preeclampsia.
\end{abstract}

Keywords: Pre-eclampsia, Early Detection, Roll over Test

\section{PENDAHULUAN}

Pre-eklampsia merupakan penyebab utama kematian ibu dan merupakan salah satu komplikasi kehamilan yang akhir-akhir ini kasusnya semakin meningkat. Dampak pre eklamsi dapat menyebabkan kelahiran prematur, kematian perinatal, dan gangguan pertumbuhan janin di intrauterin. Pada ibu dengan pre eklamsi dapat terjadi vasokonstriksi pembuluh darah yang bisa menghambat fungsi otak, ginjal, hati dan beberapa organ vital tubuh lainnya (Pikuman. W, 2015). Insiden pre eklamsi terjadi pada 3-7\% perempuan yang baru hamil pertama kali dan $3 \%$ pada perempuan yang sudah pernah melahirkan lebih dari satu kali. Sebanyak 2,8 \% prevalensi preeklamsia berasal dari ibu hamil yang berada di negara berkembang, dan $0,6 \%$ berasal dari ibu hamil yang ada di negara maju (WHO, 2005). Secara global, hampir $99 \%$ kematian Ibu terjadi di negara berkembang, dengan rasio kematian tahun 2015 adalah 239 per 100.000 angka kelahiran hidup dibandingkan 12 per 100.000 jumlah kelahiran hidup yang ada di negara maju, hal ini masih jauh 
dari target 2030 yaitu 70 per 100.000 kelahiran hidup (WHO et al., 2015). Berdasarkan Profil kesehatan Indonesia tahun 2015, hipertensi merupakan penyumbang angka kematian ibu terbesar ke dua dan bahkan angkanya menunjukkan kecenderungan yang terus meningkat dari tahun ke tahun. Pada tahun 2010 menunjukkan (21,5\%), tahun 2011 (24,7\%), pada tahun 2012 (26,9\%) dan pada tahun $2013(27,1 \%)$.

Etiologi dari proses terjadinya pre-eklampsia belum dapat diketahui secara jelas, namun ada 3 hal yang mendasari terjadinya penyakit ini, yaitu sindrom maladaptasi, Imunologi, dan masalah malnutrisi. Beberapa faktor risiko yang berhubungan dengan perkembangan kasus ini yaitu pada primigravida, multigravida, janin yang terlalu besar, kehamilan gemelli (kembar), dan morbid obesitas. (Bobak, 2005). Perlu dilakukan pendampingan dan pemeriksaan ante natal care secara teratur dan komprehensif bagi ibu primigravida agar dapat mengetahui sejak dini komplikasi kehamilan dan tindakan konseling pra hamil, hamil dan pasca hamil. Ada beberapa metode deteksi dini untuk mengetahui faktor resiko pre eklamsi pada ibu hamil. Salah satu diantaranya adalah dengan menggunakan pemeriksaan Roll over-test. Pemeriksaan ini sangat mudah dan murah, sehingga bisa dilakukan oleh tenaga kesehatan baik di tingkat dasar maupun di pelayanan tingkat lanjut.

Hasil penelitian yang dilakukan oleh Ghojazedeh dkk (2013) tentang pengukuran roll over test (ROT) pada ibu hamil didapatkan bahwa secara siginifikan nilai ROT positif lebih tinggi pada kelompok yang ibu hamil yang mengalami preeklampsia.Hal tersebut Sejalan dengan temuan Walia dkk (2015) dimana nilai ROT lebih dari $15 \mathrm{mmHg}$ pada ibu hamil normal berisiko 2,191 kali lebih mungkin untuk terjadi preeklampsia. Penelitian lain yang dilakukan Suprihatin (2016) mengkombinasi Antara index masa tubuh (IMT), Mean arteria Pressure (MAP) dan Roll Over-test (ROT) untuk memprediksi hipertensi dalam kehamilan menunjukkan bahwa dari $90 \%$ sampel yang masuk kedalam kondisi preeklampsia $85 \%$ diantaranya mampu di diagnosa positif melalui kombinasi ini yaitu apabila ibu hamil memiliki 2 atau lebih tanda positif diantara IMT, MAP dan ROT.

Pre eklamsia dapat terjadi pada usia kandungan diatas 20 minggu, dan biasanya banyak ditemukan pada usia kehamilan 37 minggu, namun pre eklamsi juga dapat timbul pada pertengahan usia kehamilan. Tingginya angka morbiditas pada kasus pre-eklamsia ibu hamil, tidak menutup kemungkinan dapat meningkatkan angka kematian ibu hamil dan melahirkan akibat pre-eklamsia. Hal tersebut dapat terjadi jika deteksi dini dan penanganan awal kasus pre-eklamsia tidak dilakukan dengan segera dan tepat.

Hal yang dapat menjadi pertanyaan adalah apakah kejadian pre eklamsi dapat dicegah dengan deteksi dini faktor resiko. Apakah pemeriksaan dengan menggunakan roll over test dapat memprediksi kejadian pre eklamsi sejak dini? 
Apakah deteksi dini pre eklamsi dapat mencegah komplikasi dan kematian pada ibu hamil? Tulisan ini akan membahas tentang roll over test (ROT) sebagai prediksi pre eklamsi pada ibu hamil

\section{Pre eklamsi}

\section{KAJIAN TEORI}

Ada dua proses perubahan yang menjadi dasar patogenesis dari preeklamsia. Pertama adalah : hipoksia pada plasenta yang terjadi karena berkurangnya aliran darah dalam arteri spiralis. Kondisi ini dapat terjadi karena adanya kegagalan invasi sel trofoblas pada dinding arteri spiralis pada awal kehamilan dan pada awal trimester kedua, sehingga arteri spiralis tidak dapat melebar dengan sempurna yang mengakibatkan terjadinya penurunan aliran darah dalam ruangan intervilus di plasenta yang dapat menyebabkan hipoksia pada plasenta (Reslan \& Khalil, 2010). Kedua adalah adanya stress oksidatif, yaitu adanya zat toksin yang masuk ke seluruh tubuh dan dapat merangsang terjadinya kelainan pada sel endotel pembuluh darah (disfungsi endotel) dan dapat terjadi pada seluruh permukaan endotel pembuluh darah pada organ penderita preeklampsia. Pada disfungsi endotel terjadi ketidakseimbangan produksi zat - zat yang bertindak sebagai vasokontriktor seperti endotelium I, tromboksan dan angiosintesin II hal tersebut menyebabkan terjadinya penyempitan pembuluh darah yang luas dan terjadilah hipertensi (Reslan \& Khalil, 2010).

Pre-eklampsia merupakan salah satu komplikasi kehamilan dengan proses patofisiologi yang kompleks. Penyebab utama adalah adanya kelainan pada plasenta. Adanya gangguan invasi dari arteri spiralis oleh sel sitotrofoblas pada uterus yang sebenarnya merupakan jalur diferensiasi yang unik di mana sel-sel janin mengadopsi atribut tertentu dari endotelium maternal yang biasa mereka gantikan. Pada kasus pre-eklampsia, proses differensiasi ini menjadi kacau. Gangguan pada kasus ini dapat dikaitkan dengan jalur oksida nitrat, yang berkontribusi besar pada kontrol kekuatan otot vaskular. Selain itu, penghambatan sintesis maternal nitrat oksida mencegah implantasi embrio. Peningkatan resistensi arteri uterina merangsang kepekaan yang lebih tinggi terhadap vasokonstriksi dan dengan demikian iskemik plasenta kronis dan stres oksidatif. Iskemia plasenta kronis ini menyebabkan komplikasi janin, termasuk retardasi pertumbuhan intrauterin dan kematian intrauterin. Secara berurutan, stres oksidatif merangsang pelepasan ke sirkulasi maternal zat diantaranya radikal bebas, lipid teroksidasi, sitokin, dan faktor pertumbuhan endotel vaskular larut serum. Kelainan ini bertanggung jawab untuk disfungsi endotel dengan hiperpermeabilitas vaskular, trombofilia, dan hipertensi, sehingga dapat mengkompensasi penurunan aliran di arteri uterina karena vasokonstriksi perifer. 
Disfungsi endotel bertanggung jawab untuk gejala klinis yang diamati pada penderita pre eklamsi diantaranya, kerusakan endotelium pada hati yang berkontribusi pada terjadinya sindrom HELLP (Hemolisis, liver enzim dan Rendah Trombosit), gangguan endotelium otak yang menyebabkan gangguan neurologis refrakter, atau bahkan eklamsia. Menipisnya faktor pertumbuhan endotel vaskular di podocytes menyebabkan endotelosis dapat untuk memblokir diafragma celah di membran basal, menyebabkan terjadinya penurunan filtrasi glomerulus dan dapat terjadi proteinuria. Sehingga, disfungsi endotel meningkatkan anemia hemolitik mikroangiopati, dan hiperpermeabilitas vaskular yang berdampak pada rendahnya albumin serum sehingga menyebabkan edema, terutama di tungkai bawah atau paru-paru.

Pada preeklampsia dapat terjadi spasme pembuluh darah yang disertai dengan retensi garam dan air. Hasil biopsi ginjal pada penderita pre eklamsi ditemukan spasme hebat pada arteriola glomerulus. Selain itu pada beberapa kasus, lumen arteriola menjadi sangat sempit sehingga hanya dapat dilalui oleh satu sel darah merah. Jika semua pembuluh darah arteri dalam tubuh mengalami penyempitan, maka tekanan darah akan naik sebagai usaha untuk mengatasi kenaikan tekanan perifer agar oksigenasi jaringan dapat dicukupi. Sedangkan adanya kenaikan berat badan dan edema dikarenakan penumpukan air yang berlebihan dalam ruangan interstitial. Proteinuria dapat terjadi oleh spasme arteriola sehingga aliran darah ke ginjal dan fungsi glomerulus menurun.

\section{Roll Over Test (ROT)}

Setiap wanita yang hamil pada umumnya akan mengalami perubahan fisiologis yang terjadi untuk mempertahankan kondisi kehamilan tetap berjalan dengan normal. Salah satu perubahan fisik yang terjadi adalah perubahan sistem kardiovaskular. Curah jantung akan meningkat 20\% pada usia kehamilan 8 minggu sehingga memungkinkan untuk terjadi vasodilatasi perifer. Hal ini dipengaruhi oleh sel endotel, termasuk sintesis oksidat nitrat, yang diregulasi oleh estradiol dan prostaglandin (PGI2). Vasodilatasi perifer menyebabkan $25-30 \%$ jatuh kedalam kondisi resistensi vaskular sistemik dan untuk mengimbangi hal ini curah jantung akan meningkat $40 \%$ selama kehamilan. Kondisi ini dicapai terutama melalui peningkatan volume stroke yang rendah dan peningkatan denyut jantung. Maksimal curah jantung ditemukan pada usia kehamilan sekitar 20 - 28 minggu (Priya, 2016). Pada kenyataannya tidak semua ibu hamil mampu beradaptasi dengan perubahan fisiologis yang terjadi akibat kehamilannya, sehingga proses perubahan yang seharusnya fisiologis terjadi menjadi terganggu dan jatuh kedalam kondisi yang patologis.

Roll Over Test (ROT) adalah pengukuran tekanan darah pada dua posisi yang berbeda, yaitu pada posisi tidur sisi kiri dan posisi tidur terlentang. ROT dikatakan positif jika terjadi perubahan/peningkatan tekanan darah diastolik antara 
posisi tidur samping dan terlentang $\geq 15 \mathrm{mmHg}$ dan negatif saat perubahan diastol $<15 \mathrm{mmHg}$ (Suprihatin and Norontoko, 2015). Tes ini dikenal dengan nama RollOver Test yang pertama sekali diperkenalkan oleh Gant dan dilakukan pada usia kehamilan 28 - 32 minggu. (Kaytri, 2016) dan Ghojazadeh (2013) melakukannya pada usia 24 - 28 minggu. Pasien berbaring dalam posisi miring ke kiri, selanjutnya pasien diukur tekanan darahnya, kemudian dicatat dan diulangi sampai tekanan darah tidak berubah. Langkah berikutnya pasien tidur terlentang dan dicatat kembali tekanan darahnya. Tes dianggap positif bila selisih tekanan darah menunjukkan $20 \mathrm{mmHg}$ atau lebih (Walia, D and Gupta, 2015; Kaytri, 2016).

\section{Roll Over Test dengan Hipertensi dalam Kehamilan}

Pada umumnya ibu hamil akan mengalami perubahan hematologi yang fisiologis. Dimana terdapat efek yang mendalam antara posisi ibu terhadap profil hemodinamik pada ibu dan janin. Pada posisi terlentang tekanan dari Vena Cava Inferior (VCI) menyebabkan penurunan aliran balik Vena ke jantung dan mengakibatkan volume stroke dan kardiac output menurun. Berbalik dari lateral ke posisi terlentang dapat 85 mengakibatkan penurunan curah jantung sebesar $25 \%$, sehingga menyebabkan terganggunya aliran darah uteroplasenta (Sherwood, 2014). Terganggunya aliran uteroplasenta menyebabkan terjadinya perubahan nilai profil hemodinamik antara ibu dan janin seiring dengan meningkatnya tekanan darah. Posisi Ibu Hamil terlentang dan miring kiri terhadap Vena Cava Inferior (Sherwood, 2014). Adanya respon hipertensi yang terjadi pada perubahan posisi ibu hamil 28 - 32 minggu dari miring menjadi terlentang merupakan prediktor terjadinya hipertensi gestasional. Ibu hamil dengan test positif juga menunjukkan kepekaan yang tidak normal terhadap angiostensin II. Placental bed pada kehamilan normal dan preeklampsia. Pada preeklampsia, perubahan fisiologi pada arteri uteroplasenta tidak melewati desiduamiometrial junction sehingga terdapat segmen yang menyempit antara arteri radialis dengan desidua (Brown, 2011).

Walia (2015) yang melibatkan $200 \mathrm{ibu}$ hamil, menyatakan bahwa ROT positif pada usia kehamilan 28 dan 30 minggu berisiko 2 kali untuk terjadi preeklampsia. Temuan Kaytri (2016) dalam penelitiannya yang melibatkan 54 ibu hamil trimester 1 mendapatkan hasil bahwa ROT mampu memprediksi hipertensi pada kehamilan dengan spesifitas $77,77 \%$ dengan prediktif positif $64,7 \%$. Pada umumnya ibu hamil akan mengalami perubahan 165 hematologi dan anatomi yang fisiologis. Dimana terdapat efek yang mendalam antara posisi ibu terhadap profil hemodinamik pada ibu dan janin. Pada posisi terlentang tekanan dari Vena Cava Inferior (VCI) menyebabkan penurunan aliran balik Vena ke jantung dan mengakibatkan volume stroke dan kardiac output menurun. Berbalik dari lateral ke posisi terlentang dapat mengakibatkan penurunan curah jantung sebesar 25\%, sehingga menyebabkan terganggunya aliran darah uteroplasenta (Sherwood, 2014). Perubahan anatomi juga memberikan dampak terhadap nilai ROT, dimana semakin 
tua usia kehamilan, maka proses perubahan anataomi akan semakin besar dan menekan pembuluh darah vena dan aorta saat posisi terlentang sehingga menyebabkan aliran utero plasenta terganggu. Terganggaunya aliran uteroplasenta menyebabkan terjadinya perubahan nilai profil hemodinamik antara ibu dan janin seiring dengan meningkatnya tekanan darah. Ibu hamil dengan test ROT positif dapat mengindikasikan kepekaan yang abnormal terhadap angiostensin II.

\section{KESIMPULAN}

1) Deteksi dini pre eklamsi dapat membantu mengurangi angka kesakitan dan kematian pada ibu akibat pre eklamsi

2) Roll over test mampu memprediksi kejadian pre eklamsi pada usia kehamilan di atas 24 minggu

Berdasarkan hasil kajian, selanjutnya petugas kesehatan direkomendasikan untuk memberikan edukasi dan motivasi pada ibu hamil supaya aktif melakukan pemeriksaan ante natal care secara komprehensif

\section{DAFTAR PUSTAKA}

Brown, C. M. and Garovic, V. D. 2011. Mechanisms And Management Of Hypertension In Pregnant Women. Current Hypertension Reports. 13(5). pp. 338-346. doi: 10.1007/s11906-011 -0214-y.

Ghojazadeh, M. et al. 2013. Prognostic Risk Factors For Early Diagnosing Of Preeclampsia In Nulliparas. Nigerian medical journal : journal of the Nigeria Medical Association. 54(5). pp. 344-8. doi: 10.4103/0300-1652.122368.

Reslan, O. M. and Khalil, R. A. 2010. Molecular And Vascular Targets In The Pathogenesis And Management Of The Hypertension Associated With Preeclampsia. Cardiovascular \& hematological agents in medicinal chemistry. 8(4), pp. 204-26. doi: 0.2174/187152510792481234

Pikuman, W. (2015). Kejadian Preeklamsia Pada Ibu Hamil (Studi Analitik Di RS. St. Fatimah Makasar Tahun 2015). Karya Tulis Ilmiah. Tidak di Publikasikan.

Priya, K. et al. 2016. Association Between Hypertension And Quality Of Life In Pregnancy. Hypertension in pregnancy. 1955(March). pp. 1 -9. doi: 10.3109/10641955.2016.1143485.

Kaytri, S. 2016. Role Of Uterine Artery Doppler And Roll Over Test In Prediction Of Pregnancy Induced Hypertension. International Journal of Reproduction, Contraception, Obstetrics and Gynecology. 5(10). pp. 3556-3559.

Sherwood, L. 2014. Fisiologi Manusia Dari Sel ke Sistem. Edisi 8. Edited by B. U. Pendit et al. Jakarta: EGC 
Suprihatin, E. and Norontoko, D. A. 2015. Prediction of Preeclampsia by a Combination of Body Mass Index (BMI), Mean Arterial Pressure (MAP), and Roll Over Test (ROT). (November).

Walia, M., D, A. S. and Gupta, G. 2015. Comparison Between Roll-Over Test And Placental Localization For Early Prediction Of Preeclampsia. International Journal of Reproduction, Contraception, Obstetrics and Gynecology. 4(December). pp. 1710-1713

WHO, et al. 2015. Trends In Maternal Mortality: 1990 to 2015. Executive Summary. WHO Library Cataloguing. p. 14. doi: 10. 